\title{
Ecosystem Effects in the Lower Mississippi River Basin
}

Chapter L of 2011 Floods of the Central United States
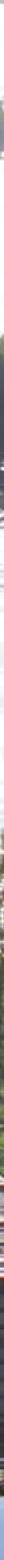

U.S. Department of the Interior

U.S. Geological Survey 
Cover. View of flooding from Nebraska City, Nebraska, looking east across the Missouri River, August 2, 2011. Photograph by Robert Swanson, U.S. Geological Survey (USGS). 


\section{Ecosystem Effects in the Lower Mississippi River Basin}

By D. Phil Turnipseed, Yvonne C. Allen, Brady R. Couvillion, Karen L. McKee, and William C. Vervaeke

Chapter L of

2011 Floods of the Central United States

Professional Paper 1798-L 


\title{
U.S. Department of the Interior SALLY JEWELL, Secretary
}

\section{U.S. Geological Survey Suzette M. Kimball, Acting Director}

\author{
U.S. Geological Survey, Reston, Virginia: 2014
}

For more information on the USGS - the Federal source for science about the Earth, its natural and living resources, natural hazards, and the environment, visit http://www.usgs.gov or call 1-888-ASK-USGS.

For an overview of USGS information products, including maps, imagery, and publications, visit http://www.usgs.gov/pubprod

To order this and other USGS information products, visit http://store.usgs.gov

Any use of trade, firm, or product names is for descriptive purposes only and does not imply endorsement by the U.S. Government.

Although this information product, for the most part, is in the public domain, it also may contain copyrighted materials as noted in the text. Permission to reproduce copyrighted items must be secured from the copyright owner.

Suggested citation:

Turnipseed, D.P., Allen, Y.C., Couvillion, B.R., McKee, K.L., and Vervaeke, W.C., 2014, Ecosystem effects in the Lower Mississippi River Basin: U.S. Geological Survey Professional Paper 1798-L, 17 p., http://dx.doi.org/10.3133/pp1798L.

ISSN 2330-7102 (online) 


\section{Contents}

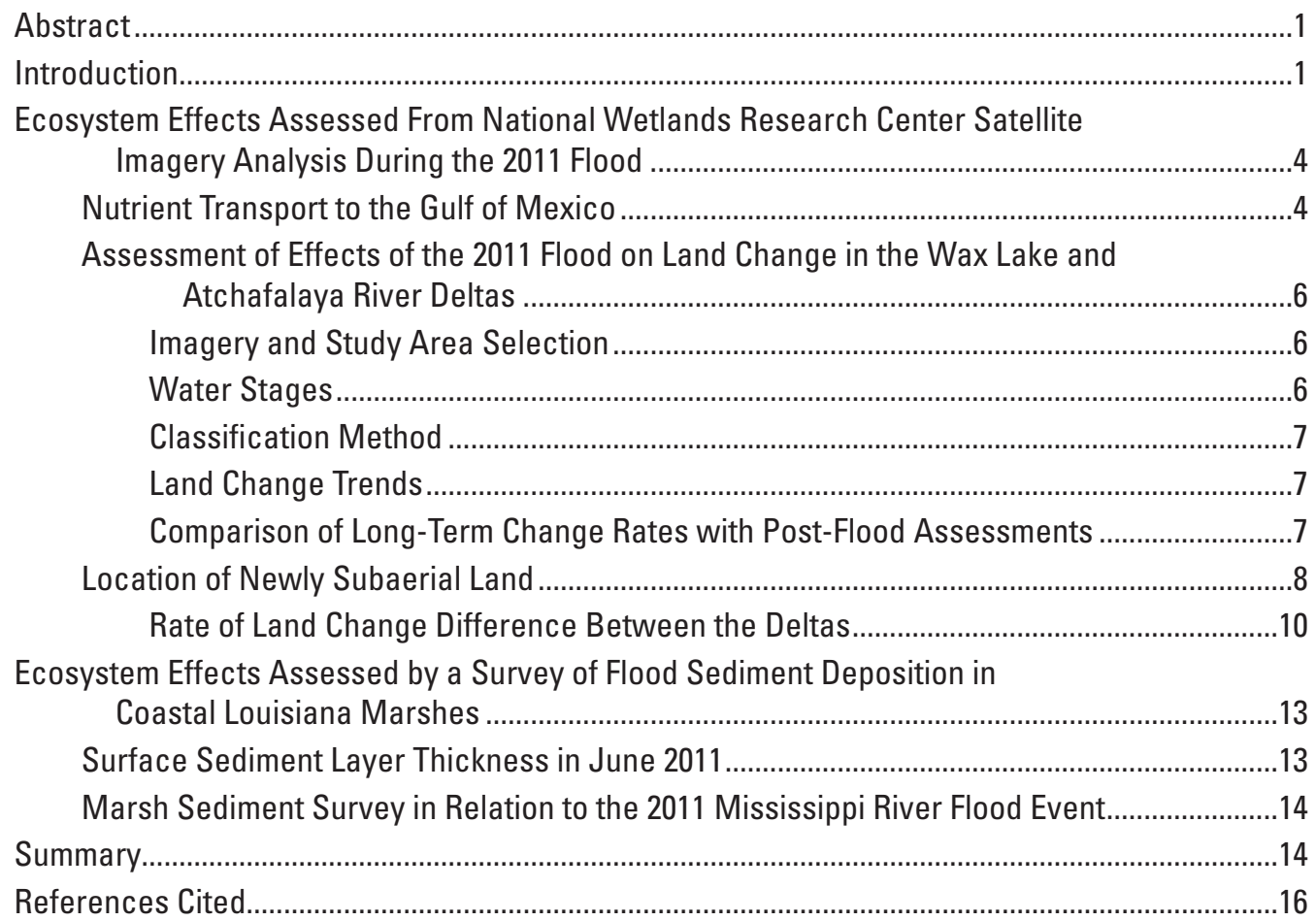




\section{Figures}

1. Map showing the Lower Mississippi River Basin in Mississippi and Louisiana, and selected streamgage streamflow data

2. Graph showing annual total nitrogen flux and streamflow for the combined Mississippi and Atchafalaya River Basins

3. Map showing National Aeronautics and Space Administration Moderate Resolution Imaging Spectroradiometer satellite image showing three large areas of sediment, or plumes, moving through the floodwaters across Louisiana on May 17, 2011

4. Graph showing land area estimates for the Atchafalaya River Delta .8

5. Graph showing land area estimates and land change trend for the Atchafalaya River Delta compared with the same measures for the Wax Lake Delta .9

6. Maps showing depiction of new subaerial land from 2010 to 2012

7. Map showing depiction of delta progradation in the Wax Lake and Atchafalaya River Deltas as determined by the first occurrence of subaerial land. Dates depicted indicate land that was first observed on or before the date listed.

8. Map showing light detection and ranging (lidar) elevation of the Wax Lake and Atchafalaya River Deltas captured in January 2011.

9. Graph showing total streamflow comparison for recent water years at the Atchafalaya River at Morgan City, Louisiana, and the Wax Lake Outlet at Calumet, Louisiana

10. Graph showing streamflow measured at the Wax Lake Outlet streamgage from January 2008 to July 2012

11. Photographs showing marsh sediment sampling completed in June 2011 across four basins [Atchafalaya, Terrebonne, Barataria, Mississippi River Delta (Birdsfoot)] in coastal Louisiana. 


\section{Conversion Factors}

SI to Inch/Pound

\begin{tabular}{|c|c|c|}
\hline Multiply & By & To obtain \\
\hline \multicolumn{3}{|c|}{ Length } \\
\hline centimeter $(\mathrm{cm})$ & 0.3937 & inch (in.) \\
\hline millimeter (mm) & 0.03937 & inch (in.) \\
\hline micrometer (um) & 0.00003937 & inch (in.) \\
\hline kilometer (km) & 0.6214 & mile (mi) \\
\hline kilometer (km) & 0.5400 & mile, nautical (nmi) \\
\hline meter $(\mathrm{m})$ & 1.094 & yard (yd) \\
\hline \multicolumn{3}{|c|}{ Area } \\
\hline hectare (ha) & 2.471 & acre \\
\hline hectare (ha) & 0.003861 & square mile $\left(\mathrm{mi}^{2}\right)$ \\
\hline square kilometer $\left(\mathrm{km}^{2}\right)$ & 0.3861 & square mile $\left(\mathrm{mi}^{2}\right)$ \\
\hline \multicolumn{3}{|c|}{ Flow rate } \\
\hline cubic meter per second $\left(\mathrm{m}^{3} / \mathrm{s}\right)$ & 70.07 & acre-foot per day (acre-ft/d) \\
\hline meter per second $(\mathrm{m} / \mathrm{s})$ & 3.281 & foot per second $(\mathrm{ft} / \mathrm{s})$ \\
\hline \multicolumn{3}{|c|}{ Mass } \\
\hline kilogram (kg) & 2.205 & pound avoirdupois (lb) \\
\hline metric ton per year & 1.102 & ton per year (ton/yr) \\
\hline
\end{tabular}

Temperature in degrees Celsius $\left({ }^{\circ} \mathrm{C}\right)$ may be converted to degrees Fahrenheit $\left({ }^{\circ} \mathrm{F}\right)$ as follows: ${ }^{\circ} \mathrm{F}=\left(1.8 \times{ }^{\circ} \mathrm{C}\right)+32$

Temperature in degrees Fahrenheit ( $\left.{ }^{\circ} \mathrm{F}\right)$ may be converted to degrees Celsius $\left({ }^{\circ} \mathrm{C}\right)$ as follows: ${ }^{\circ} \mathrm{C}=\left({ }^{\circ} \mathrm{F}-32\right) / 1.8$

Vertical coordinate information is referenced to the North American Vertical Datum of 1988 (NAVD 88).

Horizontal coordinate information is referenced to the North American Datum of 1983 (NAD 83). 



\title{
Ecosystem Effects in the Lower Mississippi River Basin
}

\author{
By D. Phil Turnipseed, Yvonne C. Allen, Brady R. Couvillion, Karen L. McKee, and William C. Vervaeke
}

\section{Abstract}

The 2011 Mississippi River flood in the Lower Mississippi River Basin was one of the largest flood events in recorded history, producing the largest or next to largest peak streamflow for the period of record at a number of streamgages on the lower Mississippi River. Ecosystem effects include changes to wetlands, nutrient transport, and land accretion and sediment deposition changes. Direct effects to the wetland ecosystems in the Lower Mississippi River Basin were minimized because of the expansive levee system built to pass floodwaters. Nutrients carried by the Mississippi River affect water quality in the Lower Mississippi River Basin. During 2011, nutrient fluxes in the lower Mississippi River were about average. Generally, nutrient delivery of the Mississippi and Atchafalaya Rivers contributes to the size of the hypoxic zone in the Gulf of Mexico. Based on available limited post-flood satellite imagery, some land expansion in both the Wax Lake and Atchafalaya River Deltas was observed. A wetland sediment survey completed in June 2011 indicated that recent sediment deposits were relatively thicker in the Atchafalaya and Mississippi River (Birdsfoot) Delta marshes compared to marshes farther from these rivers.

\section{Introduction}

The 2011 flood resulted from a combination of excess rainfall and melting of larger than normal snowpacks in the upper basin upstream of Cairo, Illinois, during the spring of 2011 (Vining and others 2013). Precipitation that was 125 to 150 percent above normal in April 2011 in the upper Ohio and Mississippi River Basins (U.S. Department of Commerce, 2012), in concert with above-average snowmelt runoff, resulted in substantial streamflows on the lower Mississippi River. Floods of this magnitude in the Lower Mississippi River Basin have the potential to have large effects on the ecosystems in this area, including the Lower Mississippi River, the Atchafalaya River, and the Gulf of Mexico. The National Weather Service correctly forecasted that the spring 2011 Mississippi River flood would be substantial and rival or exceed previous major floods in 1927 and 1937. The pressures on the levee systems from the high river flows were such that the U.S. Army Corps of Engineers (USACE) opened a number of spillways including the Morganza Spillway (fig. 1, not opened since 1973) and the Bonnet Carré Spillway (fig. 1, not opened since 2008) upstream from New Orleans, Louisiana (DeHaan and others, 2012).

The flooding began in late spring in the Lower Mississippi River Basin and fell below flood stage at Baton Rouge, La., in late June 2011 (Holmes and others, 2013). The 2011 Mississippi River flood had the largest or near largest peak streamflow on the lower Mississippi River at a number of streamgages for the period of record (Holmes and others, 2013). The record peak streamflow of 2,310,000 cubic feet per second $\left(\mathrm{ft}^{3} / \mathrm{s}\right)$ as measured at the Mississippi River at Vicksburg, Mississippi [U.S. Geological Survey (USGS) downstream streamgage number 07289000 (fig. 1)] on May 17,2011 , surpassed the record of 2,278,000 $\mathrm{ft}^{3} / \mathrm{s}$ set in May 1927 (Holmes and others, 2013). This streamgage measures the largest volume of water on the river and is the most downstream continuous USGS streamgage before the Old River Control Structure near Simmesport, La. The Old River Control Structure was built to regulate the flow of water from the Mississippi River into the Atchafalaya River in an effort to prevent the Mississippi River from changing course. As a result of constant monitoring, approximately 30 percent of the flow of the Mississippi River is diverted down the Atchafalaya River where it combines with the flow from the Red River (DeHaan and others, 2012).

Many of the effects to the wetland ecosystems in the Lower Mississippi River Basin from the 2011 flood on the Mississippi River were minimized because of the expansive levee system built to pass floodwaters. During 2011, nutrient fluxes in the lower Mississippi River were about normal (Aulenbach and others, 2011), as the 2011 annual flux of nitrogen was just above the 1980 to 2011 average of 1,460,000 tons (fig. 2) . Generally, nutrient delivery by the Mississippi and Atchafalaya Rivers to the Gulf of Mexico contributes to the size of that hypoxic zone (Turner and Rabalais, 1994).

This chapter summarizes the activities and research products produced by the USGS National Wetlands Research Center (NWRC) and its partner agencies in response to the flood of 2011. The NWRC has long-term ecosystem monitoring and research projects in the Lower Mississippi and Atchafalaya River Basins, with major objectives to measure ecosystem response to floodwaters, to research the effects of sediment concentrations and loads, to assess sediment load delivery (both geospatially as well as how sediment load 


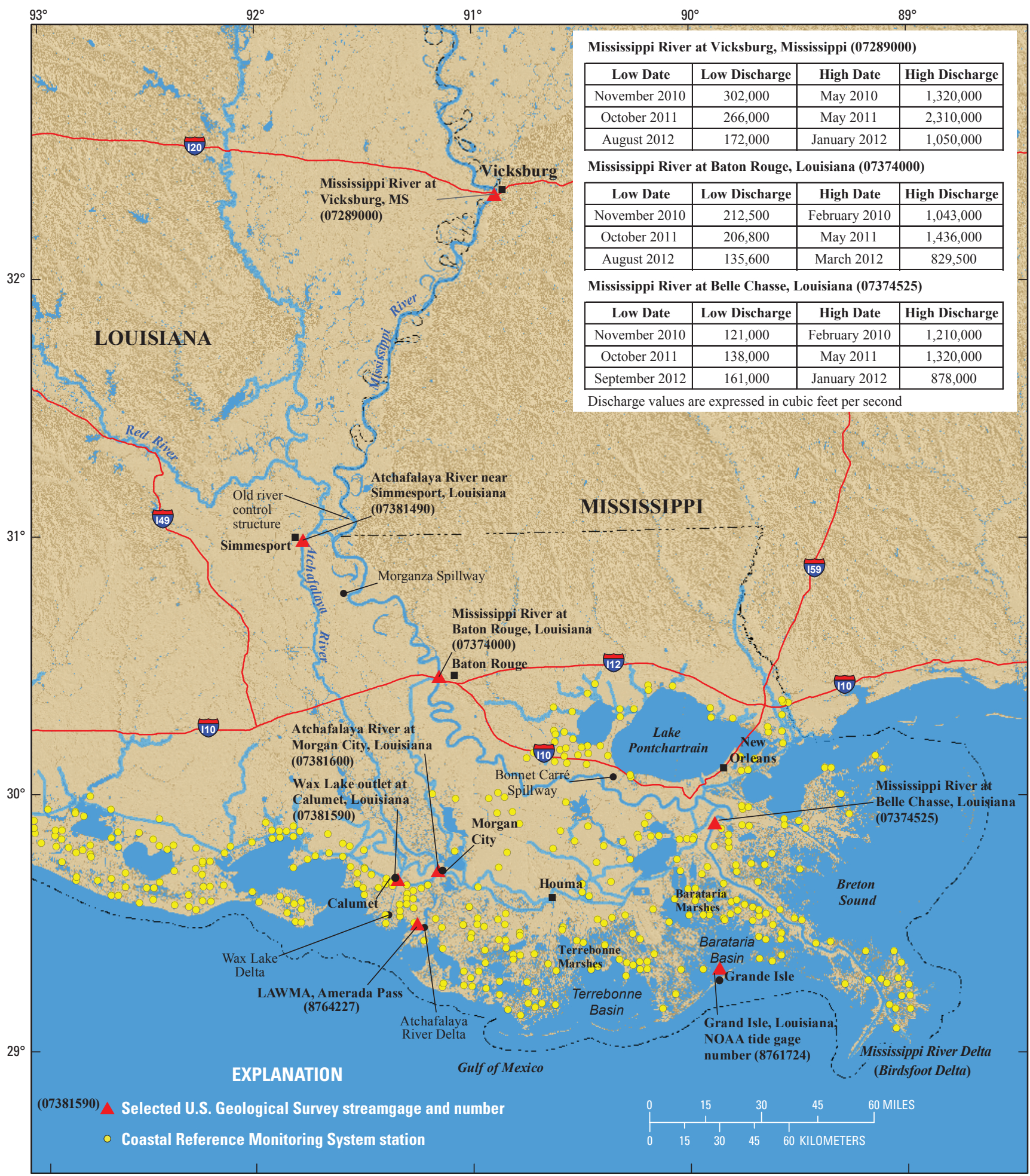

Figure 1. The Lower Mississippi River Basin in Mississippi and Louisiana, and selected streamgage streamflow data. 


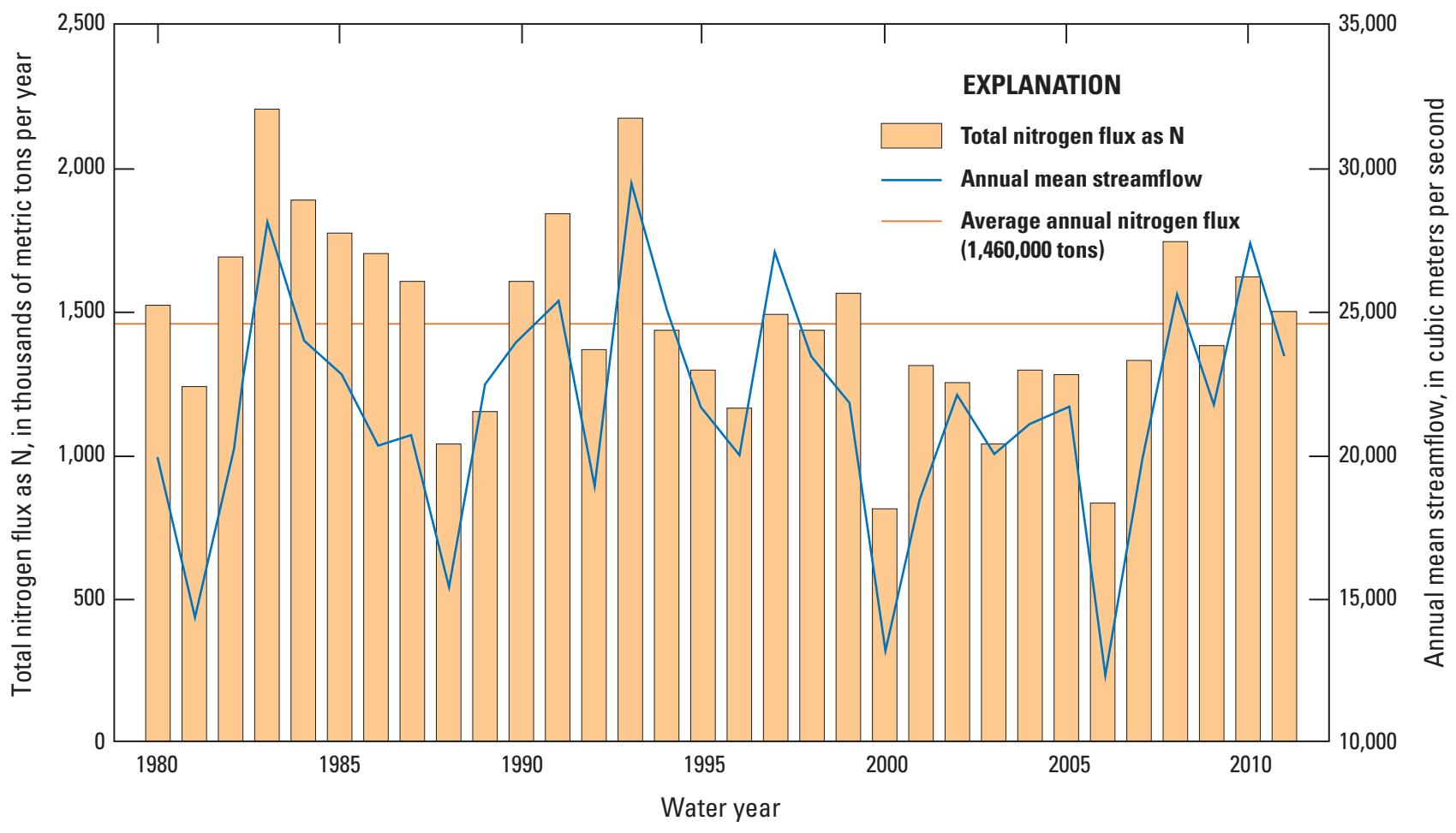

Figure 2. Annual total nitrogen flux and streamflow for the combined Mississippi and Atchafalaya River Basins [Aulenbach and others, (2007) and updated through 2011 from U.S. Geological Survey ( 2014a)].

delivery relates to the geotechnical aspects of the system), and to help determine water quality from the Mississippi River Basin to the Gulf of Mexico. The USGS operates a nationwide network of real-time streamgages that are used to record river streamflows (http://waterwatch.usgs.gov/). This network includes multiple streamgages located along the lower Mississippi River. U.S. Geological Survey personnel also work with the Coastwide Reference Monitoring System (CRMS), a multiagency network with experts and tools for monitoring water quality and ecosystems, and for measuring long-term continuous ecological water-quality responses to events such as the record 2011 flood on the lower Mississippi River (Steyer, 2010). The CRMS data can be accessed through the Coastal Wetlands Planning, Protection and Restoration Act Web site at http://lacoast.gov, and represent the largest coastal wetland monitoring network of its kind in the world. The CRMS and USGS streamgage data were critical in determining ecosystem effects (floral and fauna response, sediment transport, and so forth) in the Lower Mississippi River Basin concurrent with and following the 2011 flood (fig. 1).
The NWRC and USACE used satellite datasets collected before, during, and after the flood, along with aerial imagery, to help characterize and describe the effects of the flood and the sediment transport during this historic event in the Lower Mississippi River Basin, as well as determine patterns of land change in the Wax Lake and Atchafalaya River Deltas before and after the flood. The NWRC collected aerial imagery and video of the Morganza Spillway, the Bonnet Carré Spillway, and other locations before, during, and after the flood to document effects on ecosystems in the Lower Mississippi River and Atchafalaya River Basins. Based on available limited post-flood satellite imagery, a focused land change analysis was completed for the Wax Lake and Atchafalaya River Deltas. To assess sediment deposition in coastal marshes and the potential effects of the 2011 Mississippi River flood event on marsh vertical accretion, a coastwide survey was completed spanning four basins in Louisiana [Atchafalaya, Terrebonne, Barataria, and Mississippi River (known as the "Birdsfoot" Delta)]. 


\section{Ecosystem Effects Assessed From National Wetlands Research Center Satellite Imagery Analysis During the 2011 Flood}

As the floodwaters moved down through the Lower Mississippi River Basin, the Morganza Spillway upstream of Baton Rouge, La., was opened for the first time since 1973, allowing part of the Mississippi River to flow through the Atchafalaya River Basin, whereas the Bonnet Carré Spillway, upstream of New Orleans, La., was opened to divert floodwaters from the Mississippi River into Lake Pontchartrain. The USGS worked closely with the National Aeronautics and Space Administration (NASA) to download, process, and analyze data from the Moderate Resolution Imaging Spectroradiometer (MODIS) instrument on NASA's Aqua satellite to help characterize this epic event.

Satellite images showed locations of substantial sediment transport throughout coastal Louisiana as a result of flooding on the Mississippi River. The USGS and NASA provided satellite imagery to the USACE and the State of Louisiana to assist with flood response efforts. These satellite images clearly and concisely showed three large areas of sediment, or plumes, moving out into the Gulf of Mexico from the floodwaters flowing through southeast Louisiana (fig. 3). The Bonnet Carré Spillway consists of two basic components: a control structure along the east bank of the Mississippi River and a floodway that conveys diverted floodwaters to Lake Pontchartrain. The opening of the Bonnet Carré water control structure resulted in a plume into Lake Pontchartrain. Another plume was the combined result of opening the Morganza Spillway and flooding on the Atchafalaya River conveyed through the Old River Control Structure near Simmesport, La. The third plume formed at the present day (2013) Mississippi River Delta where the Mississippi River meets the Gulf of Mexico, also known as the "Birdsfoot" Delta (fig. 3).

The main focus of the NWRC during the flood was to provide accurate, relevant, and timely data to emergency response officials and government agencies with responsibility for the protection of life and property, and to learn more about how events like these affect coastal ecosystems. One mission of the NWRC during this event was to better understand how and where sediments move into wetlands in the Atchafalaya and Mississippi River Deltas, with intent to provide knowledge to create more effective restoration projects. Aerial imagery from May 17, 2011, coincided with the peak stage and streamflow at the Mississippi River at Vicksburg, Miss. (USGS downstream streamgage number 07289000; fig. 1).

The National Aeronautics and Space Administration provided the NWRC with the imagery in figure 3 from MODIS as part of an ongoing commitment by NASA's Applied Science and Technology Project Office at the John C. Stennis Space
Center in Bay St. Louis, Miss. Working directly with NASA, the NWRC uses data from agency satellites to help communities address issues of concern, such as forest management and coastal erosion.

Satellites, such as NASA's Aqua and the USGS-operated Landsat, are crucial to providing information to monitor the extent and the effects of natural hazards, such as floods and hurricanes. Satellite images have been used in the past to track algal blooms that occurred in Lake Pontchartrain after the 2008 opening of the Bonnet Carré Spillway (Mize and Demcheck, 2009). These satellite images allow managers to gain a better perspective of regional effects in a timely fashion. Flood images clearly illustrated the movement of Mississippi River fresh water into the salty water of Lake Pontchartrain and ultimately into the Gulf of Mexico. The satellite images helped scientists determine how fast the floodwaters were traveling through Lake Pontchartrain and provided imagery on sediment transport throughout the system.

Seasonal flooding is a natural event in the Lower Mississippi River Basin and is essential to the health of wetland ecosystems. Extreme floods deliver high amounts of sediment and nutrients to the wetlands from the Mississippi River in central and southeast Louisiana. Through the years, the measured loss of delta and coastline land represents a loss of valuable coastal habitat and biodiversity. Floodwaters, rich in sediment, provide the primary source for sustaining and even expanding the size of deltas. The Wax Lake and Atchafalaya River Deltas (fig. 1) are affected regularly by seasonal flooding from the Atchafalaya River and provide two examples of the positive effects that flooding can have on growing land through river diversion.

\section{Nutrient Transport to the Gulf of Mexico}

Nutrient delivery (nitrogen and phosphorous), particularly during the months of April and May, has been identified as one of the primary factors controlling the size of the northern Gulf of Mexico hypoxic zone (Turner and others, 2012), which is the largest hypoxic zone (human induced) in the western hemisphere and one of the largest in the world (Obenour and others, 2013). The USGS releases preliminary estimates of monthly nutrient fluxes from the Mississippi and Atchafalaya Rivers to the Gulf of Mexico in early June each year. These estimates, along with other data, are used by researchers supported by the National Oceanic and Atmospheric Administration (NOAA) to predict the size of the annual hypoxic zone. Nutrient flux data are available online at http://toxics.usgs.gov/hypoxia/mississippi/flux_ests/index.html. Tracking spring and annual loads of nutrients delivered to the Gulf of Mexico helps State and Federal partners serving on the Gulf of Mexico Alliance Hypoxia Task Force to measure progress towards lessening nutrient runoff and reducing the size of the hypoxic zone. 


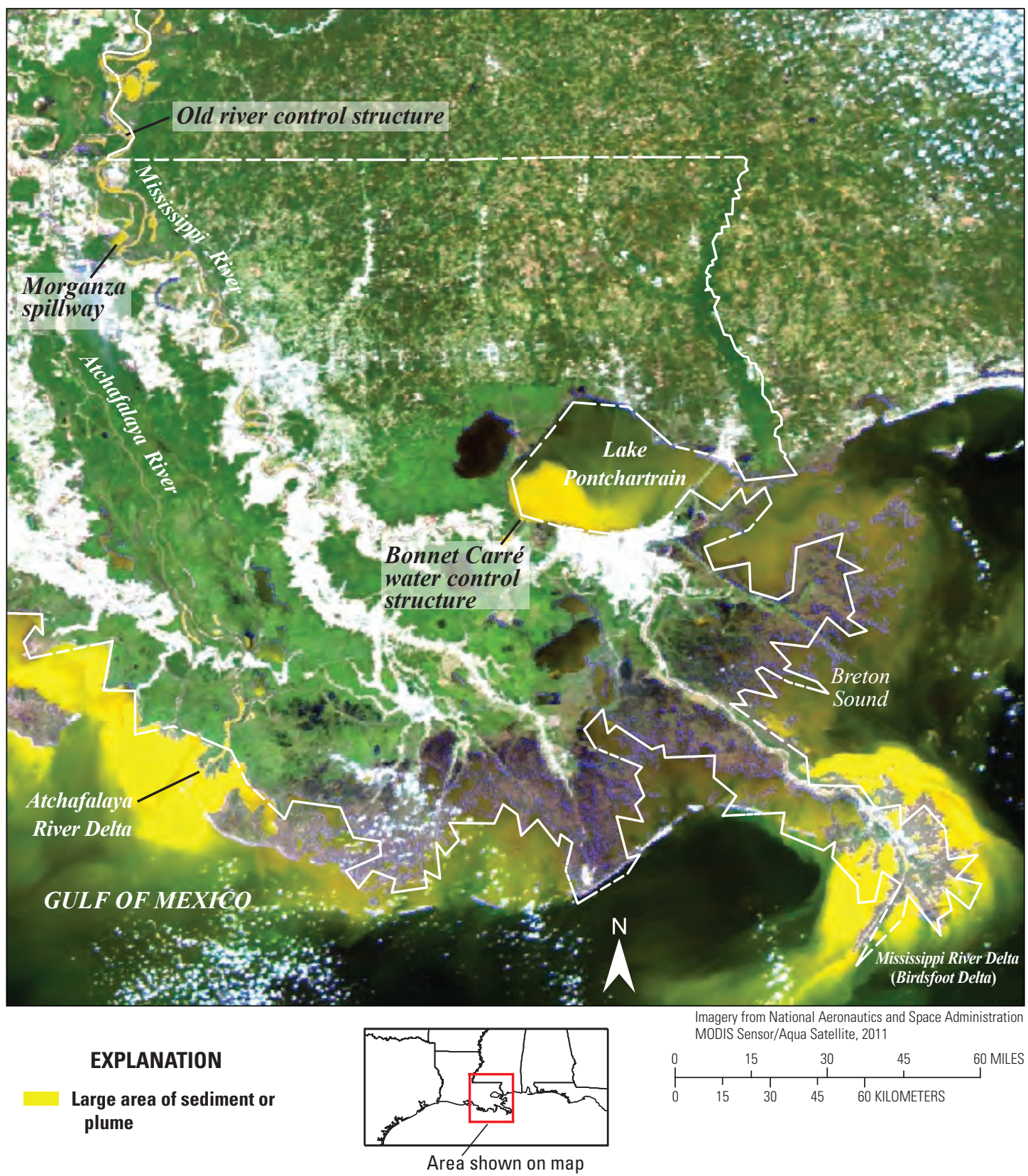

Figure 3. National Aeronautics and Space Administration Moderate Resolution Imaging Spectroradiometer satellite image showing three large areas of sediment, or plumes, moving through the floodwaters across Louisiana on May 17, 2011. 
During 2011, nutrient flux, in the form of total nitrogen, in the lower Mississippi River was about normal [Aulenbach and others (2007) and updated for 2011 using data from U.S. Geological Survey, 2014a], and below the record set in 1983 (fig. 2). Generally, the nutrient delivery of the Mississippi and Atchafalaya Rivers is related to the magnitude of flows.

\section{Assessment of Effects of the 2011 Flood on Land Change in the Wax Lake and Atchafalaya River Deltas}

Although most of coastal Louisiana faces the ongoing challenges associated with chronic land loss, the Wax and Atchafalaya River Deltas represent two of the few places with some measure of land gain. The Wax Lake Delta lies at the mouth of the Wax Lake Outlet (fig. 1) and has been largely allowed to form naturally since it first became subaerial after the 1973 flood. The Atchafalaya River Delta lies at the mouth of the Atchafalaya River and its growth has been augmented by intentionally placed material dredged from the Atchafalaya River navigation channel (Louisiana Coastal Wetland Conservation and Restoration Task Force, 1993).

The NWRC, working with the USACE Engineer Research and Development Center (ERDC), completed an extensive USGS Landsat analysis in the fall and winter of 2011 and in the late winter and early spring of 2012 to provide a post-2011 flood assessment of land changes in the Wax Lake and Atchafalaya River Deltas. Allen and others (2012) used multitemporal observations of remotely sensed Landsat satellite imagery to determine land change trends for the Wax Lake Delta and a nearby reference marsh from 1983 to 2010. Because changing river and tide stages can affect the amount of exposed land area, the approach used in Allen and others (2011) relied on multiple observations of land extent coupled with water level (stage) measurements at the time of image capture to determine long-term land change trends corrected by water stages. The current study used the same techniques to examine the long-term land change trends in the Atchafalaya River Delta from 1983 to 2010 and also to extend the temporal analysis window to compare long-term land change trends for both deltas with observations of land area after the 2011 flood.

\section{Imagery and Study Area Selection}

To determine long-term land change trends in the Atchafalaya River Delta, 72 Landsat 5 and Landsat 7 images (path 23 , rows 39 and 40) spanning 1983-2010 were classified into categories of land and water. All imagery was downloaded from the USGS Global Visualization Viewer (http://glovis. usgs.gov). All selected images were cloud-free over the area of interest and were corrected for radiance and reflectance.
Preprocessing of all datasets included use of ERDAS IMAGINE (ERDAS Inc., Norcross, Georgia, http://www.hexagongeospatial.com/products/ERDAS-IMAGINE/details.aspx). Only Landsat 5 and full coverage Landsat 7 Scan Line Corrector (SLC)-on images were used to determine long-term land change trends. Although limited in resolution to 30 meters (m), Landsat imagery offers several key features that make it appropriate for this application:

1. Landsat satellite records images of the same area every 16 days,

2. Satellite images allow for instantaneous synoptic views of the entire study area, and

3. Shortwave-infrared (SWIR) sensors on Landsat allow for objective and automated delineation of water bodies.

In November 2011, onboard electrical problems caused Landsat 5 to cease routine acquisitions. Landsat 7 continues to acquire imagery but has been operating with SLC off since 2003 (U.S. Geological Survey, 2014b). The SLC-off imagery contains missing scan lines and does not yield 100-percent coverage.

\section{Water Stages}

Reported tide stages at Grand Isle, La. (NOAA tide gage number 8761724; http://tidesandcurrents.noaa.gov/geo. shtml? location $=8761724$ ) and river stages at Morgan City, La. (USGS streamgage number 07381600; http://waterdata. usgs.gov/la/nwis/uv/?site_no $=07381600 \& P A R A m e t e r$ $c d=00065,72020,63160,00060$ ) were used to determine regional variation in river and tide stages. These two streamgages have nearly continuous datasets for the entire study period. For more recent years, a streamgage located at the Atchafalaya River Delta [LAWMA, Amerda Pass, Louisiana, NOAA streamgage 8764227; http://tidesandcurrents. noaa.gov/geo.shtml? location $=8764227$ ] also was used to test if a single, more proximate streamgage would improve model predictive capability. Data from the LAWMA streamgage were only available from 2006 to 2011. For all streamgages, water stage closest to the time of acquisition for Landsat 5 (path 23, rows 39 and 40) was used in the analysis. Time was formatted as year and fractions of a year down to the hour of imagery capture.

The mean stage from 1983 to 2012 at the Grand Isle tidal gage was 1.93 plus or minus $( \pm) 0.18 \mathrm{~m}$. The mean stage for only those dates having Landsat imagery was $1.83 \pm 0.21 \mathrm{~m}$. The long-term mean stage at the Atchafalaya River at Morgan City streamgage from 1983 to 2012 was $1.01 \pm 0.44 \mathrm{~m}$. The mean stage for dates in this analysis having associated Landsat imagery was $0.92 \pm 0.47 \mathrm{~m}$. The mean LAWMA stage for dates in this analysis (2006-12) having associated Landsat imagery $(n=21)$ was $2.21 \pm 0.25 \mathrm{~m}$. 


\section{Classification Method}

Because water increasingly absorbs light in the near and SWIR wavelengths, sensors that are sensitive in this spectrum have increased capacity to delineate water boundaries. Band 5 of Landsat (1.55-1.75 micrometers, SWIR) has been widely relied on to discriminate water bodies from land (Frazier and Page, 2000). Classification methods used in this study for delineating land and water, a simple threshold of band 5, are the same as outlined in Allen and others (2012). Note that classification efforts focused on discriminating water from all other land categories; therefore, the definition of "land" in this study area may include exposed mudflats, floating aquatic vegetation, marsh, and forested areas.

\section{Land Change Trends}

Differences in water stage can have an obvious effect on the amount of land exposed in coastal Louisiana, but daily and seasonal changes in water stage are not drivers of actual land change. Allen and others (2011) determined that by including both tidal and riverine gage information along with time in a multiple linear regression, the coefficients of determination increased compared to results using simple linear regression with time as the sole predictor variable. Building off of the results of Allen and others (2011), which focused on the Wax Lake Delta, the same approach was used in the current study to determine long-term land change trends in the Atchafalaya River Delta. In the current study, time, tidal gage, and riverine streamgage were all used as predictor variables of land area in the Atchafalaya River Delta for the same three time periods analyzed by Allen and others (2012): 1983-2010, 1983-2002, and 2002-10. Projected rates of long-term land change for the Atchafalaya River Delta were calculated by using the coefficients generated from the regression output and by assuming average tidal and riverine water stage for the time period of interest.

All statistical analyses were completed by using Systat Software Inc., version 13 (http://www.systat.com/ SystatProducts.aspx). The land area estimates were square root transformed to reduce problems of nonhomogeneous residuals. This transformation is more appropriate in analyses where the response variable, land area in this case, may not drop below zero.

Allen and others (2012) determined that long-term land change trends for the Wax Lake Delta differed greatly depending on the period analyzed. In the current study, land change trends for the Atchafalaya River Delta did not differ greatly when reported by time period. Coefficients of determination $\left(r^{2}\right)$ for land change in the Atchafalaya River Delta for the time period 1983-2010 $\left(r^{2}=0.79\right)$ were similar to $1983-2002$ $\left(r^{2}=0.81\right)$ and only slightly lower for $2002-10\left(r^{2}=0.64\right)$. By contrast, Allen and others (2012) reported high coefficients of determination for the time period for the Wax Lake Delta during $1983-2010$ and $1983-2002\left(r^{2}=0.73\right.$ and 0.85 , respectively), but a much lower coefficient of determination for 2002-10 $\left(r^{2}=0.23\right)$.

Average rates of land change for each time period can be computed by using the appropriate multiple regression coefficients along with average tidal and riverine stages for that time period (fig. 4). From 1983 to 2010, land area corrected by water stage in the Atchafalaya River Delta increased at a rate of 1.7 square kilometers per year $\left(\mathrm{km}^{2} / \mathrm{yr}\right)$. This rate is higher than reported by Allen and others (2012) for the same time period for the Wax Lake Delta $\left(0.9 \mathrm{~km}^{2} / \mathrm{yr}\right)$. Land change trends for the Atchafalaya River Delta for the 1983-2002 and 2002-10 time periods were 2.1 and $2.5 \mathrm{~km}^{2} / \mathrm{yr}$, respectively. Land change trends for the Wax Lake Delta reported by Allen and others (2012) for the 1983-2002 and 2002-10 time periods were much lower: 1.0 and $0.01 \mathrm{~km}^{2} / \mathrm{yr}$, respectively.

Ideally, an examination of the effect of water stage on land area would rely on stream-gaging data that were collected in closer proximity than Grand Isle and Morgan City, La. [130 and 28 kilometers $(\mathrm{km})$ from the Atchafalaya River Delta, respectively]. The LAWMA streamgage is located directly adjacent to the Atchafalaya River Delta and should provide an improved estimate of the relation between land area and water stage, but the streamgage has only been operational since 2006 and lacks the long-term historical record available for other gages. To assess any potential differences between using a single more proximate gage and the combination of two more distant gages, a similar multiple regression analysis was done using time and water stage at the LAWMA gage as predictor variables of land area for the Wax Lake and Atchafalaya River Deltas with imagery collected from 2006 to 2010. Results obtained using the more proximate LAWMA streamgage did not improve the multiple regression relation compared with results obtained using the combination of the riverine and tidal gages for either delta. For the Atchafalaya River Delta, $r^{2}=0.62$ using the LAWMA gage alone is compared with $r^{2}=0.64$ for 2002-10 using two streamgages at Grand Isle and Morgan City. For the Wax Lake Delta, $r^{2}=0.29$ using the LAWMA gage alone is compared with $r^{2}=0.23$ for 2002-10 using two streamgages reported in Allen and others (2011).

\section{Comparison of Long-Term Change Rates with Post-Flood Assessments}

Land area estimates and long-term land change trend lines reported by Allen and others (2012) for the Wax Lake Delta compared with results from this study for the Atchafalaya River Delta are shown in figure 5. As described above, these long-term land change trend lines were calculated by using the regression model coefficients and average water stage for distinct time periods. Recent (2010-12) land area observations not used in calculation of long-term land change trends also are shown on figure 5. 
There were few full coverage suitable post-flood images captured before the Landsat 5 satellite stopped collecting imagery in fall 2011 (fig. 5, darker blue boxed area). The observed land areas for the Wax Lake Delta were all higher than the 2002-10 land change trend line based on average water stage, but this pattern also seemed to be evident before the onset of the historic 2011 flood (fig. 5, light blue boxed area). By using the regression coefficients from 2002-10 regression models and water stage observed when each image was captured, predicted land areas for the Atchafalaya River and Wax Lake Deltas were calculated for images captured from mid-2010 through 2012. Note that none of these images were used to generate model inputs. The average observed land area for the Wax Lake Delta was 14.3 \pm 3.6 square kilometers $\left(\mathrm{km}^{2}\right)$ higher than predicted based on regression and observed water-stage inputs. For the Atchafalaya River Delta, the observed land area was on average $5.9 \pm 2.2 \mathrm{~km}^{2}$ higher than expected based on regression and observed water-stage inputs.

\section{Location of Newly Subaerial Land}

Delta progradation was characterized by using 95 satellite images classified to summarize land and water areas from 1973 through 2012. The datasets were derived from multiple sources including Landsat Multi-Spectral Scanner (MSS) data (1973-83), Landsat Thematic Mapper (TM) data (1984-2011), and Système Pour l'Observation de la Terre (SPOT) 4 and 5 data (2010-12). The SPOT data were used after Landsat 5 TM image acquisition ceased in late 2011.

Preprocessing of all datasets included use of ERDAS IMAGINE (ERDAS Inc., Norcross, Ga., http://www. hexagongeospatial.com/products/ERDAS-IMAGINE/details. aspx). The Landsat MSS data (1973-83), which have a native 60-m resolution, were first resampled to a 30-m resolution by using a cubic convolution resampling method to facilitate comparability with later Landsat TM-based data (native 30-m resolution). The SPOT images were similarly resampled from native resolutions of $10 \mathrm{~m}$ and $20 \mathrm{~m}$ to $30 \mathrm{~m}$ to facilitate

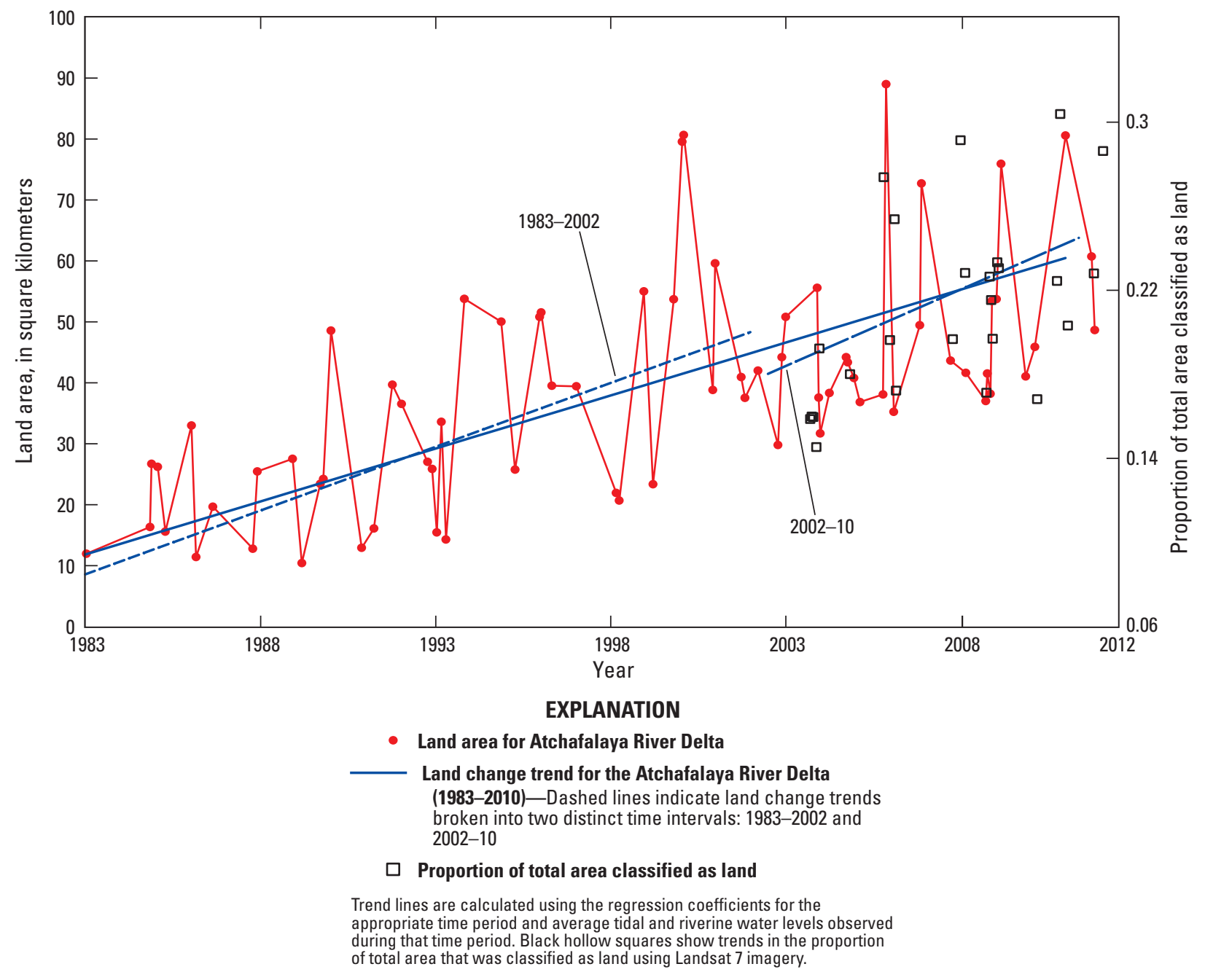

Figure 4. Land area estimates for the Atchafalaya River Delta. 
comparability with the Landsat TM record. Conducting this resampling before land-water classification is more appropriate than resampling the results of the land-water classification. All satellite imagery data were then classified into land-water categories (Couvillion and others, 2011).

Delta progradation was characterized by noting the first appearance of subaerial land in the resulting land-water datasets (fig. 6). This analysis details the first observation of subaerial land only and does not imply that these areas were always seen as land following the first observation of delta progradation. The algorithm that assigns date of first appearance of new land allows areas to alternate between subaerial and subaqueous categories as water continues to fluctuate.

The patterns of evolution of these two deltas also are shown in figure 7 . One of the most immediately evident differences in the development of these deltas is the earlier development of the Atchafalaya River Delta compared to that of the Wax Lake Delta. Larger parts of the Atchafalaya River Delta were consistently subaerial throughout the early 1970s, whereas the Wax Lake Delta did not begin to have consistent subaerial growth until the late 1970s (fig. 7). Delta progradation slowed substantially through the early 21 st century with the occurrence of multiple hurricanes and tropical storms including Lili, Katrina, Rita, Gustav, and Ike.

Observing only those areas that have become subaerial since 2010 provides insight into recent delta progradation, which can be observed on figures 6 and 8. Most newly subaerial development in the Wax Lake Delta occurred on the peripheries of the delta following the 2011 flood. As reported previously for long-term land change trends, substantial appearance of newly created lands in both deltas was already evident in 2010, before the flood of 2011 (fig. 6).

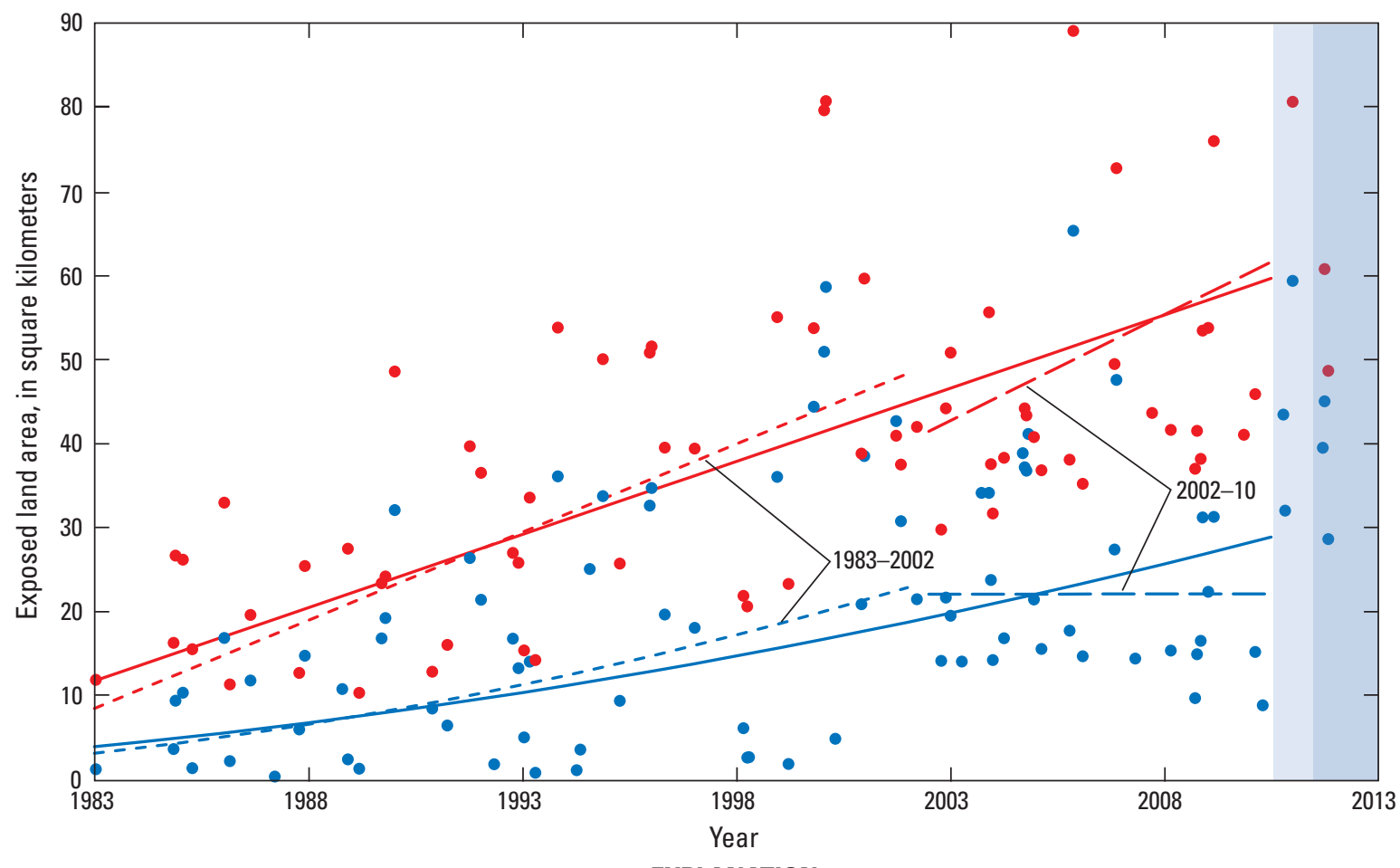

EXPLANATION

- Land area estimates for the Atchafalaya River Delta

- Land change trend for the Atchafalaya River Delta (1983-2010)—Dashed lines indicate land change trends broken into two distinct time intervals: 1983-2002 and 2002-10
- Land area estimates for the Wax Lake Delta

- Land change trend for the Wax Lake Delta (1983-2010)—Dashed lines indicate land change trends broken into two distinct time intervals: 1983-2002 and 2002-10

Trend lines are calculated by using the regression coefficients for the appropriate time period and average tidal and riverine water levels observed during that time period. All data for the Wax Lake Delta from 1983 to early 2010 is based on results reported in Allen and others (2011). The light blue boxed area shows data from mid-2010 to pre-2011 flood. The darker blue boxed area shows results from after the 2011 flood.

Figure 5. Land area estimates and land change trend for the Atchafalaya River Delta compared with the same measures for the Wax Lake Delta. 
Comprehensive system-wide measurements of in situ vertical accretion can be extremely labor intensive and costly to obtain. Remotely sensed imagery can assist in rapid, system-wide characterizations of land change, but there also are substantial challenges to this type of analysis. Landsat imagery can only be acquired according to a defined schedule, and the timing of the acquisition may not overlap well with both atmospheric and hydrologic conditions that allow for the best characterization of the habitat.

This study takes advantage of multiple measures of land area by using remotely sensed imagery to achieve a more accurate expression of the land change trends in deltaic systems that sustain not only real land change but also are subject to a host of environmental conditions that may affect the accuracy of land change measurements.

\section{Rate of Land Change Difference Between the Deltas}

Although the Wax Lake and Atchafalaya River Deltas are close to each other, their long-term and more recent land change trajectories differ substantially. Compared to the Wax Lake Delta, the Atchafalaya River Delta currently (2013) is larger and long-term land change measurements indicate it is increasing at a higher overall rate. The rate of increase for the Atchafalaya River Delta also has continued at approximately the same rate since 1983 without demonstrating the more recent plateau in land change that was reported by Allen and others (2012) for the Wax Lake Delta (fig. 5).

Unlike the Wax Lake Delta, which has been allowed to develop without substantial anthropogenic influence, the Atchafalaya River Delta lies at the mouth of an active shipping channel that is regularly dredged to maintain adequate depth for commercial navigation. Spoil from these dredging activities is regularly placed on the Atchafalaya River Delta to provide beneficial habitat for nesting birds and to increase overall landscape stability (U.S. Army Corps of Engineers, 2013a). This spoil-formed habitat is placed so that elevations do not exceed $+1.5 \mathrm{~m}$ (mean sea level), but the elevation of much of the Atchafalaya River Delta is still higher than the Wax Lake Delta (fig. 8). This higher overall elevation may have allowed for greater stability for low, unvegetated mudflats during tropical storms and winter cold front passages; consequently, the Atchafalaya River Delta may be relatively more stable than the Wax Lake Delta and neighboring marsh, which seem to have been greatly affected by these events in recent years (Allen and others, 2012). The dredged channel and higher elevation of the Atchafalaya River Delta may also reduce the opportunity for accelerated natural accretion through sediment carried by seasonal flooding.

During high river streamflows, the Atchafalaya River navigation channel also may allow for swift conveyance of sediment laden floodwaters out into the deeper parts of Atchafalaya Bay. Because the Wax Lake channels are not dredged, subaqueous development of a prodelta seaward of the Wax Lake Delta may, in fact, slow the exit of floodwaters and allow

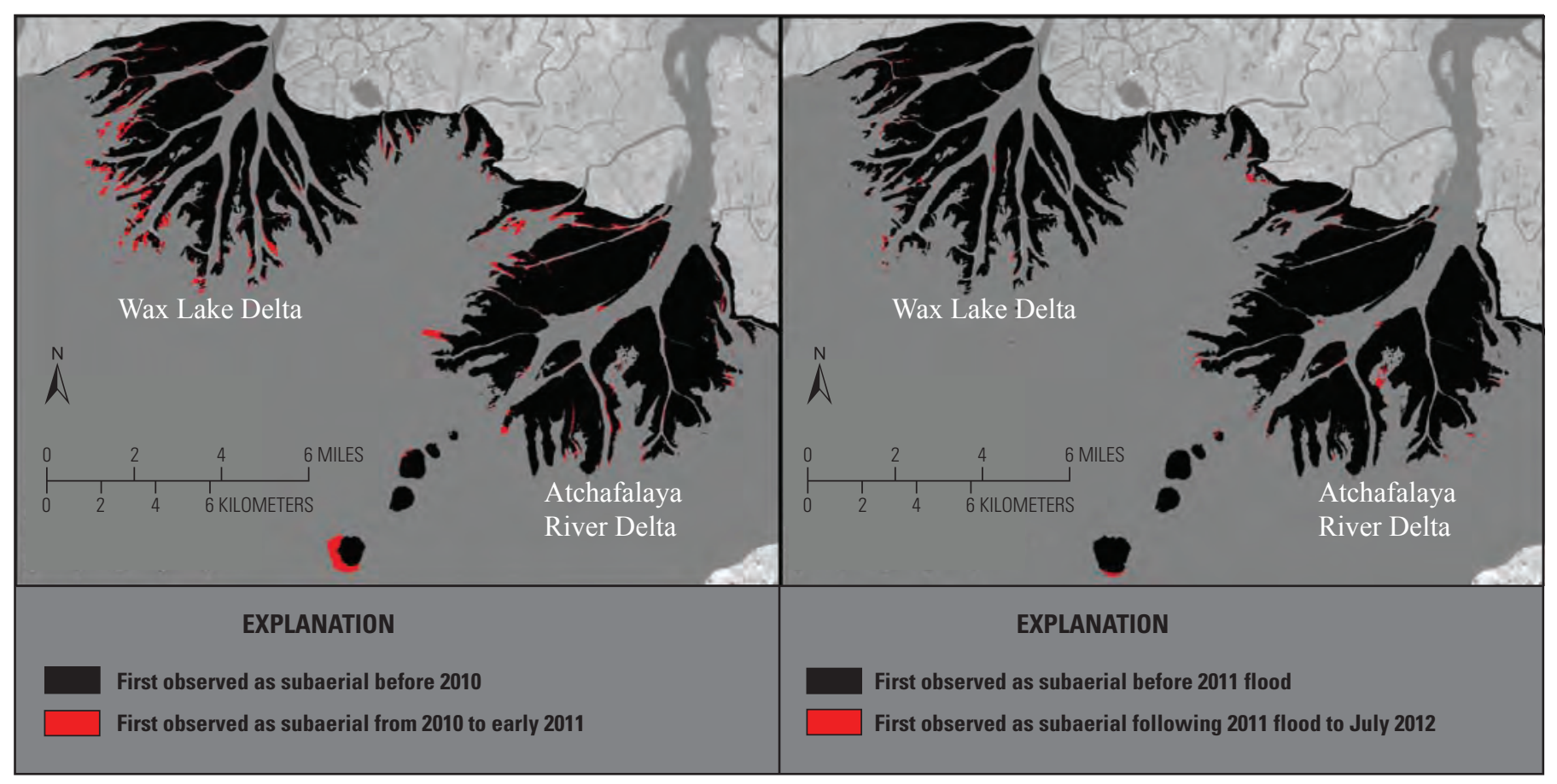

Figure 6. Depiction of new subaerial land from 2010 to 2012. 
for increased opportunity for deposition during high water events.

Based on the limited post-flood imagery available, there seems to have been some recent expansion in the Wax Lake Delta and, to a lesser extent, the Atchafalaya River Delta (fig. 7). This increased extent of land appeared, however, before the onset of the 2011 flood. Examination of hydrologic conditions preceding the flood may shed light on this observation. Total streamflow for the 2010 water year in the Atchafalaya River was remarkably high, higher than either the 2008 or 2011 water years (fig. 9). The USGS defines a water year as October 1st of the previous year to September 30th of the designated year; for example, water year 2010 is from October 1, 2009 to September 30, 2010.

High river stages in 2008 prompted an opening of the Bonnet Carré Spillway upstream from New Orleans in the spring of that year to reduce river stages on the lower Mississippi River (U.S. Army Corps of Engineers, 2014). During the fall and winter before the 2008 and 2011 flood years, however, Mississippi River streamflow at Baton Rouge (USGS

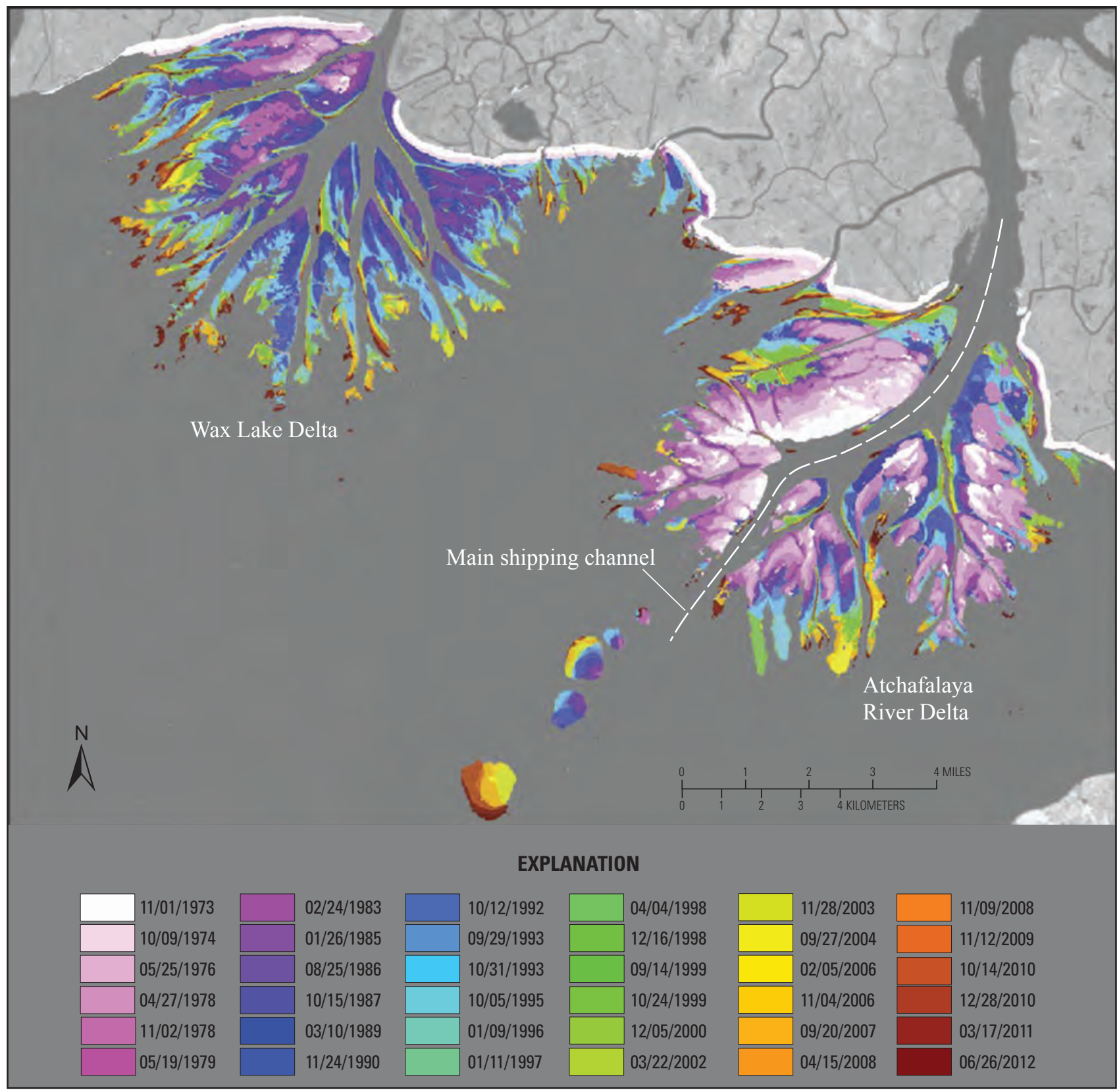

Figure 7. Depiction of delta progradation in the Wax Lake and Atchafalaya River Deltas as determined by the first occurrence of subaerial land. Dates depicted indicate land that was first observed on or before the date listed. 


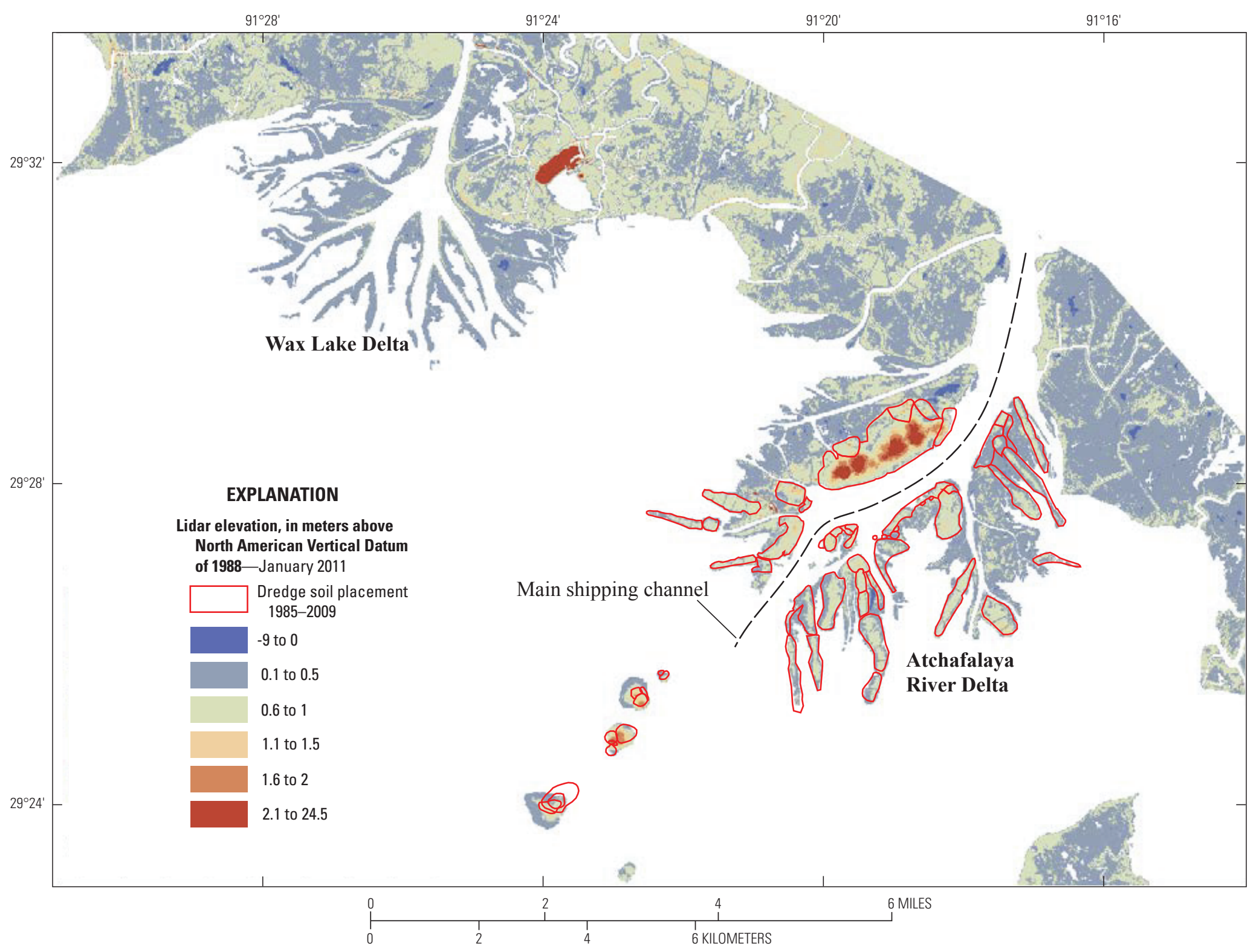

Figure 8. Light detection and ranging (lidar) elevation of the Wax Lake and Atchafalaya River Deltas captured in January 2011 (Woolpert, Inc., 2011). 
streamgage 07374000 ) was at or below median streamflow values (U.S. Geological Survey, 2014d). The record river stages at Baton Rouge seen in May 2011 rose rapidly and then also receded rapidly (U.S. Geological Survey, 2014d). By contrast, streamflow through the fall and winter of 2009 on the Atchafalaya River, as illustrated using the streamflow hydrograph for the Wax Lake Outlet at Calumet, LA streamgage (USGS streamgage 07381590), was high (fig. 10) and did not decline to seasonal lows until the following late summer, leading to extremely high total streamflow for the 2010 water year (fig. 9). This high streamflow may have been the start of the high sediment deposition on the deltas that continued through the 2011 flood year.

\section{Ecosystem Effects Assessed by a Survey of Flood Sediment Deposition in Coastal Louisiana Marshes}

To assess sediment deposition in coastal marshes and the potential effect of the 2011 Mississippi River flood event on marsh vertical accretion, a coastwide survey was completed spanning four basins in the Deltaic Plain of Louisiana (Atchafalaya, Terrebonne, Barataria, and Mississippi River
"Birdsfoot" Delta) (for detailed methods see Falcini and others, 2012; Khan and others, 2013). Potential sampling sites were identified by using aerial photography and maps. Most sites were near CRMS long-term monitoring stations maintained by the State of Louisiana's Coastal Protection and Restoration Authority (http://lacoast.gov/crms_viewer/). Additional sites were selected to provide broader coverage, especially in areas without a CRMS station. From this pool, 45 sites were randomly selected for sampling (fig. 11). Sites were accessed June 21-23 and 27, 2011, with a Bell 2063B Jet Ranger helicopter with fixed floats (fig. 11). At each site, five replicate cores were collected in a vegetated area within $5 \mathrm{~m}$ of a waterway and extruded onto a clean surface. Any incomplete or compressed cores were discarded and recollected. The thickness of the topmost sediment layer, which was visually apparent (fig. 11), was measured to the nearest millimeter, and all values were averaged to provide a mean value for each sampling site.

\section{Surface Sediment Layer Thickness in June 2011}

The thickness of the surface sediment layer varied from 0.0 to 8.3 centimeters $(\mathrm{cm})$, with a coastwide mean of $1.5 \mathrm{~cm}$. The highest average values occurred in the Atchafalaya $(2.6 \mathrm{~cm})$ and Mississippi River Delta $(1.4 \mathrm{~cm})$ marshes. Values

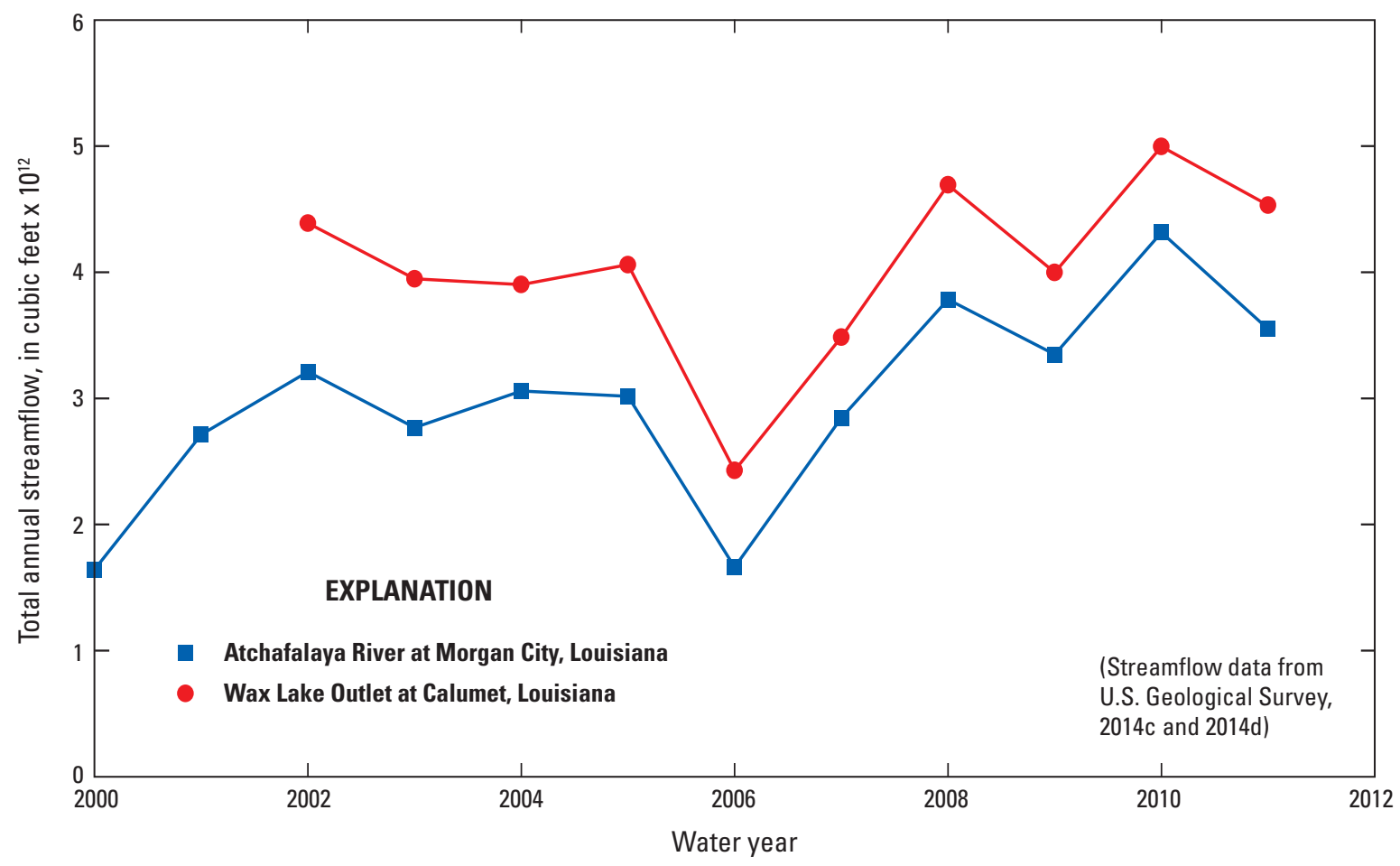

Figure 9. Total streamflow comparison for recent water years at the Atchafalaya River at Morgan City, Louisiana, (U.S. Geological Survey streamgage 07381600) and the Wax Lake Outlet at Calumet, Louisiana, (U.S. Geological Survey streamgage 07381590) streamgages. 


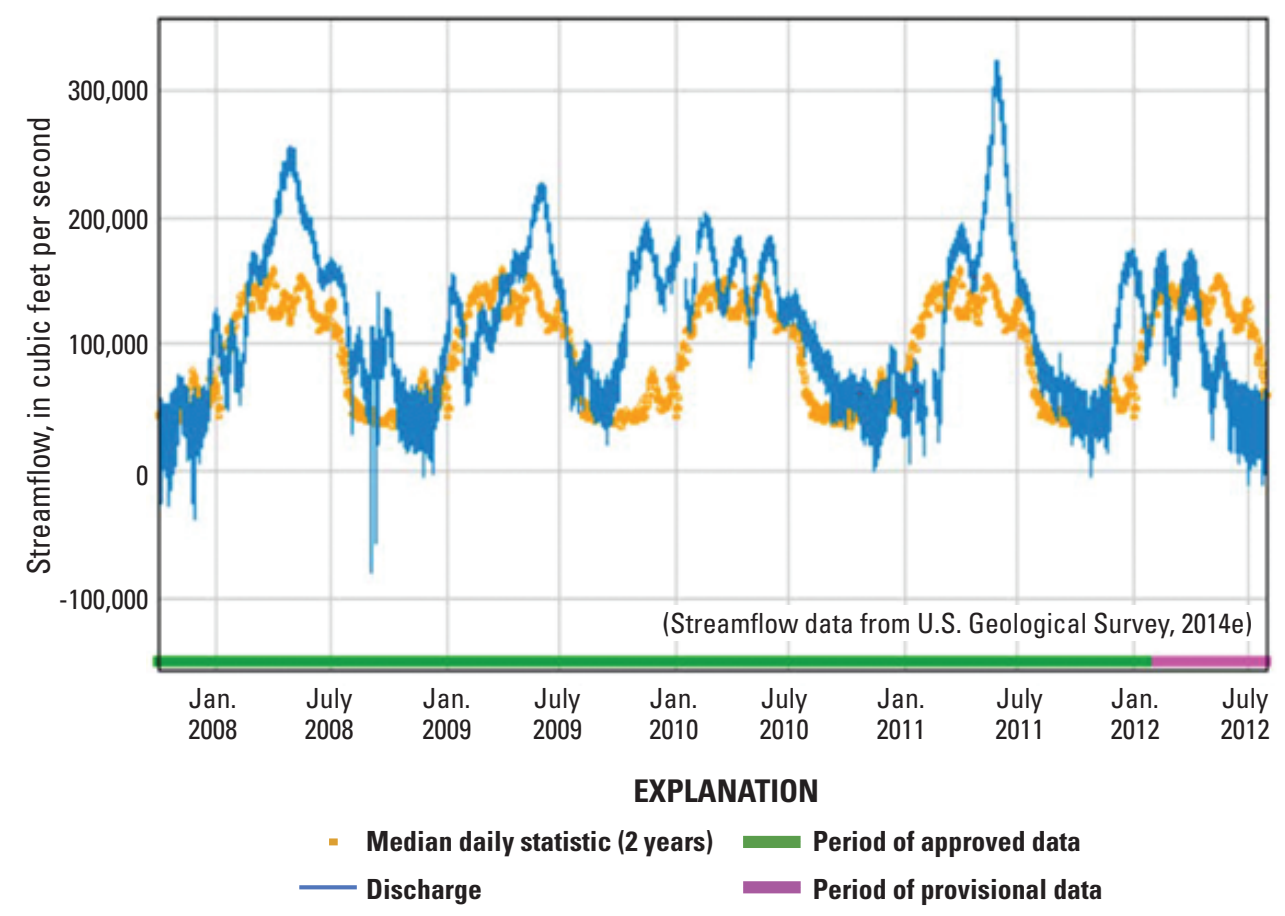

Figure 10. Streamflow measured at the Wax Lake Outlet streamgage (U.S. Geological Survey streamgage 07381590) from January 2008 to July 2012.

were considerably less in Barataria $(0.8 \mathrm{~cm})$ and Terrebonne $(0.7 \mathrm{~cm})$ marshes. Although a definite time frame cannot be ascribed to these sediments, their unconsolidated consistency and lack of plant roots indicated that they were recently deposited. Recent sediment accumulation [grams per square centimeter $\left(\mathrm{g} / \mathrm{cm}^{2}\right)$ mean +1 standard error] was estimated by multiplying the thickness of the recent sediment layer by its bulk density: Atchafalaya (1.6 \pm 1.0$)$, Barataria $(0.3 \pm 0.2)$, Mississippi River Delta (1.1 \pm 0.8$)$, Terrebonne $(0.4 \pm 0.2)$ (table 1 in Khan and others, 2013).

\section{Marsh Sediment Survey in Relation to the 2011 Mississippi River Flood Event}

The survey completed in June 2011 provided a snapshot in time of sediment deposition in coastal marshes spanning the Deltaic Plain from the Mississippi River to the Atchafalaya River. The results indicated more newly deposited sediment in marshes closest to the outlets of the two rivers, particularly the Atchafalaya River, compared to Terrebonne and Barataria marshes. Although this assessment did not account for withinmarsh variation, subsequent erosion or compaction of the measured deposit, or later sedimentation from reworked flood deposits offshore, it provided insight into how river sedimentation varied spatially and in comparison with other depositional events (for example, hurricanes: 0.8 to $2.1 \mathrm{~g} / \mathrm{cm}^{2}$; table 1 in Khan and others, 2013). The spatial pattern suggested greater potential contribution of the 2011 flood to marsh accretion in the Atchafalaya and Mississippi River Delta marshes and less to the marshes farthest from the rivers. The average sediment deposition measured in the June 2011 survey accounted for 85 percent of annual accretion recorded at CRMS sites in Atchafalaya marshes but less in the Mississippi River Delta (44 percent), Terrebonne (37 percent), and Barataria (37 percent) marshes (table 1 in Khan and others, 2013). Additional research will be required, however, to determine long-term effects of these sediments on marsh accretion and elevation dynamics as well as on marsh productivity and other ecosystem functions. More detailed analyses of these depositional patterns, as well as river sediment plumes, sediment characteristics, and sediment provenance, have been reported elsewhere (Falcini and others, 2012; Khan and others, 2013).

\section{Summary}

The 2011 Mississippi River flood in the Lower Mississippi River Basin produced the largest peak streamflows for the period of record at selected streamgages on the Lower Mississippi River. The flood was the result of a combination of excess rainfall and the coincidental melting of larger than normal snowpacks in the upper basin in the spring of 2011. Flooding began in the late spring in the lower basin and did not recede until August 2011. Peak streamflow records were 


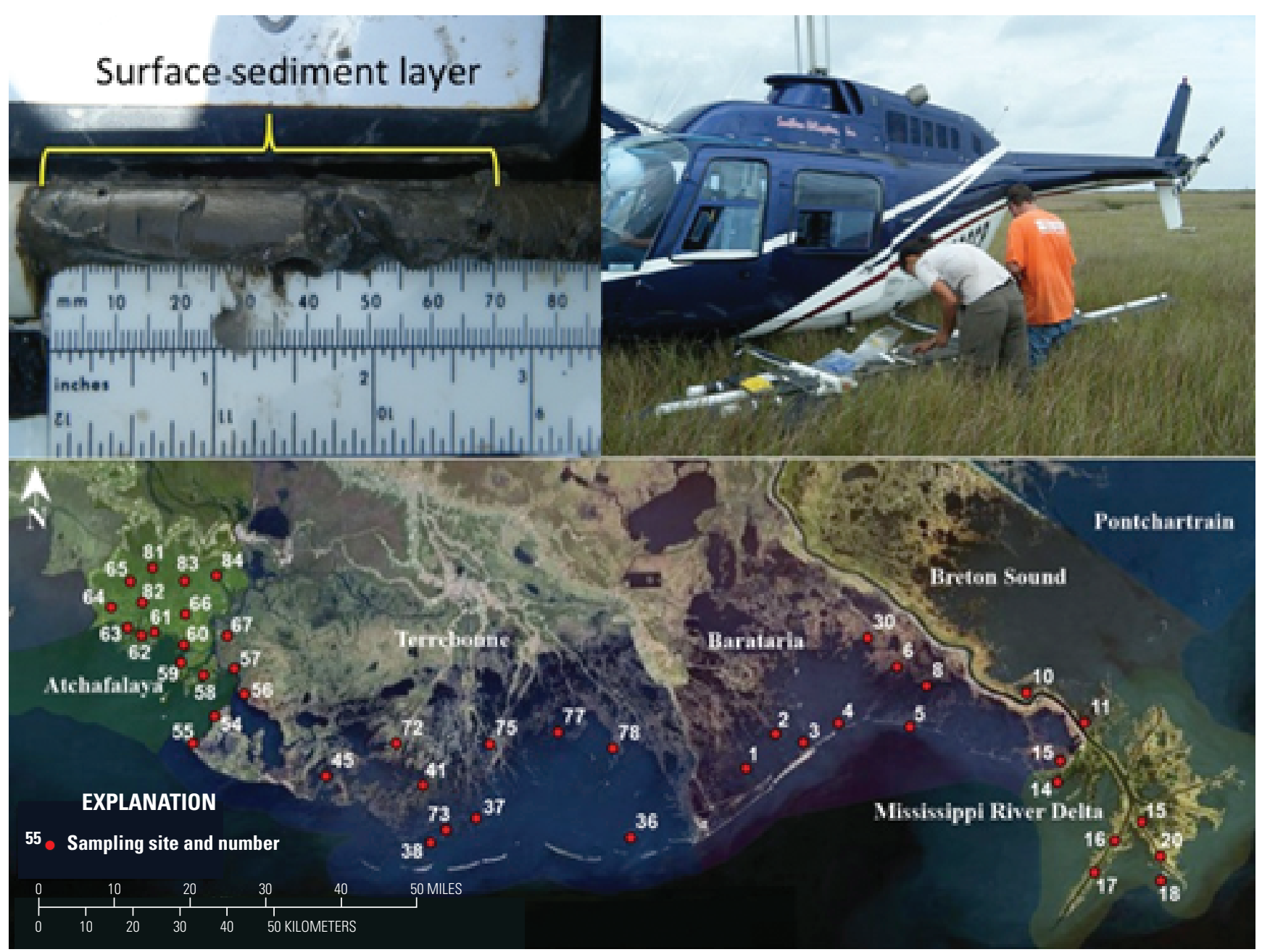

Figure 11. Marsh sediment sampling completed in June 2011 across four basins [Atchafalaya, Terrebonne, Barataria, Mississippi River Delta (Birdsfoot)] in coastal Louisiana. Clockwise from top left: Views of a typical soil core illustrating a flood deposit, helicopter sampling station in a salt marsh, and a map showing sampling site locations (Falcini and others, 2012; Khan and others, 2013).

broken on the lower Mississippi River at the streamgage located at Vicksburg, Mississippi, which typically measures the largest peak streamflows on the Mississippi River main stem during each flood. The streamgage located at Vicksburg, Mississippi, is the most downstream continuous USGS streamgage before about 30 percent of the flow of the Mississippi River is diverted down the Atchafalaya River at the Old River Control Structure near Simmesport, Louisiana. The diverted Mississippi River water combines with flow from the Red River. The record peak streamflow on the Mississippi River at Vicksburg, Mississippi, broke the record set in the Great Flood of 1927.

Direct effects of this flood event to the wetland ecosystems in the Lower Mississippi River Basin were minimal because of the expansive levee system built to pass floodwaters. During 2011, nutrient fluxes in the lower Mississippi and
Atchafalaya were about normal, and well below record. The nutrients from these rivers are transported into the Gulf of Mexico, where nutrient loading contributes to the development of the hypoxic zone in the northern Gulf of Mexico. Based on available limited post-flood satellite imagery, there seems to have been some expansion in the Wax Lake and Atchafalaya River Deltas. This increased extent of land appeared, however, before the onset of the 2011 flood. There was evidence of flood sediment delivery to marshes closest to the Atchafalaya and Mississippi River outlets, and this addition accounted for a substantial proportion of the total vertical accretion measured in permanent monitoring stations (Coastwide Reference Monitoring System) during 2011, particularly in the Atchafalaya Delta; however, further measurements are required to assess long-term effects on these wetland ecosystems. 


\section{References Cited}

Allen, Y.C., Couvillion, B.R., and Barras, J.A., 2012, Using multitemporal remote sensing imagery and inundation measures to improve land change estimates in coastal wetlands: Estuaries and Coasts, v. 35, no. 1, p. 190-200.

Aulenbach, B.T., Buxton, H.T., Battaglin, W.A., and Coupe, R.H., 2007, Streamflow and nutrient fluxes of the Mississippi-Atchafalaya River Basin and subbasins for the period of record through 2005: U.S. Geological Survey Open-File Report 2007-1080. (Also available at http://toxics.usgs.gov/ pubs/of-2007-1080/index.html.)

Couvillion, B.R., Barras, J.A., Steyer, G.D., Sleavin, William, Fischer, Michelle, Beck, Holly, Trahan, Nadine, Griffin, Brad, and Heckman, David, 2011, Land area change in coastal Louisiana from 1932 to 2010: U.S. Geological Survey Scientific Investigations Map 3164, scale 1:265,000, 12 p. pamphlet.

DeHaan, J.S., Walters, B., and others, 2012, Mississippi River and Tributaries System 2011 Post-Flood Report: U. S. Army Corps of Engineers, Mississippi Valley Division, December, 2012, 323 p.

Falcini, F., Khan, N.S., Macelloni, L., Horton, B.P., Lutken, C.B., McKee, K.L., Santoleri, R., Colella, S., Li, C., Volpe, G., D’Emidio, M., Salusti, A., and Jerolmack, D.J., 2012, Linking the historic 2011 Mississippi River flood to coastal wetland sedimentation: Nature Geoscience, v. 5, p. $803-807$.

Frazier, P.S., and Page, K.J., 2000, Water body detection and delineation with Landsat TM data: Photogrammetric Engineering and Remote Sensing, v. 66, p. 1461-1467.

Holmes, R.R., Jr., Wiche, G.J., Koenig, T.A., and Sando, S.K., 2013, Peak streamflows and runoff volumes for the Central United States, February through September, 2011: U.S. Geological Survey Professional Paper 1798-C, 60 p., accessed March 12, 2014, at http://pubs.usgs.gov/pp/1798c/.

Khan, N.S., Horton, B.P., McKee, K.L., Jerolmack, D.J., Falcini, F., Enache, M.D., and Vane, C.H., 2013, Tracking sedimentation from the historic A.D. 2011 Mississippi River flood in the deltaic wetlands of Louisiana, USA: Geology, v. 4 , no. 4, p. 391-394.
Louisiana Coastal Wetlands Conservation and Restoration Task Force, 1993, Louisiana coastal wetlands restoration plan, Atchafalaya Basin Appendix F, November 1993, 63 p., accessed March 19, 2014, at http://lacoast.gov/reports/ cwcrp/1993/AtchApndxF.pdf.

Mize, S.V., and Demcheck, D.K., 2009, Water quality and phytoplankton communities in Lake Pontchartrain during and after the Bonnet Carré Spillway opening, April to October 2008, in Louisiana, USA: Geo-Marine Letters, v. 29, no. 6 , p. 431-440.

National Oceanic and Atmospheric Administration Tides and Currents, 2013, NOAA Grand Isle Gage 8761724: National Oceanic and Atmospheric Administration, accessed June 18, 2013, at http://tidesandcurrents.noaa.gov/geo. shtml?location $=8761724$.

Obenour, D.R., Scavia, D., Rabalais, N.N., Turner, R.E., and Michalak, A.M., 2013, Retrospective analysis of midsummer hypoxic area and volume in the Northern Gulf of Mexico, 1985-2011: Environmental Science and Technology, v. 47, no. 17, p. 9808-9815.

Roberts, H.H., 1998, Delta switching - Early responses to the Atchafalaya River diversion: Journal of Coastal Research, v. 14 , no. 3 , p. $882-899$.

Shaffer, G.P., Sasser, C.E., Gosselink, J.G., and Rejmanek, M., 1992, Vegetation dynamics in the emerging Atchafalaya Delta, Louisiana, USA: Journal of Ecology, v. 80, no. 4, p. $677-687$

Steyer, G.D., 2010, Coastwide Reference Monitoring System (CRMS): U.S. Geological Survey Fact Sheet 2010-3018, 2 p. [Revised August 2010].

Systat Software Inc., 2014, Systat version 13: accessed January 30, 2014, at http://www.systat.com/SystatProducts.aspx.

Turner, R.E., Rabalais, N.N., and Justić, D., 2012, Predicting summer hypoxia in the northern Gulf of Mexico-Redux: Marine Pollution Bulletin, v. 64, no. 2, p. 319-324.

Turner, R.E., and Rabalais, N.N., 1994, Coastal eutrophication near the Mississippi river delta: Nature, v. 368, p. 619-621.

U.S. Army Corps of Engineers, 2008, Corps to Open Bonnet Carre Spillway: Corporate Communications Office, New Orleans, Louisiana, April 10, 2008, accessed March 19, 2014, at http://www2.mvr.usace.army.mil/FullStory. cfm? ID $=849$. 
U.S. Army Corps of Engineers, 2013a, Beneficial use of dredged material: U.S. Army Corps of Engineers, 1 p. [Also available at $h t t p: / / w w w . m v n . u s a c e . a r m y . m i l / P o r t a l s / 56 /$ docs/OPS/BUD/BUDMATFactSheetMay2013.pdf.]

U.S. Army Corps of Engineers, 2013b, Stage data-Lower Atchafalaya River at Morgan City, LA-Streamgage 03780: accessed June 18, 2013, at http://rivergages.mvr.usace.army. mil/WaterControl/stationinfo $2 . c f m ?$ sid $=03780 \& f i d=\& d t=S$.

U.S. Department of Commerce, 2012, Spring 2011 middle \& lower Mississippi River valley floods: U.S. Department of Commerce, National Oceanic and Atmospheric Administration, National Weather Service Assessment, 84 p.

U.S. Geological Survey, 2014a, Toxics Hydrology Program Nutrient Data: accessed March 19, 2014, at http://toxics. usgs.gov/hypoxia/mississippi/flux_ests/index.html.

U.S. Geological Survey, 2014b, Landsat Missions: accessed March 19, 2014, at http://landsat.usgs.gov/products_ slcoffbackground.php.

U.S. Geological Survey, 2014c, USGS streamgage 07381600 Lower Atchafalaya River at Morgan City, La.: U.S. Geological Survey National Water Information System, at http:// waterdata.usgs.gov/nwis/uv/?site_no=07381600\&agency_ $c d=U S G S \& a m p$

U.S. Geological Survey, 2014d, USGS streamgage 07374000 Mississippi River at Baton Rouge, La.: U.S. Geological Survey National Water Information System, at http:// waterdata.usgs.gov/nwis/uv/?site_no $=07374000 \&$ agency $c d=U S G S \& a m p$

U.S. Geological Survey, 2014e, USGS streamgage 07381590 Wax Lake Outlet at Calumet, La.: U.S. Geological Survey National Water Information System, accessed January 15, 2014, at http://waterdata.usgs.gov/nwis/uv/?site_ $n o=07381590 \&$ agency_cd $=U S G S \& a m p ;$.

Vining, K.C., Chase, K.J., and Loss, G.R., 2013, General weather conditions and precipitation contributing to the 2011 flooding in the Mississippi River and Red River of the North Basins, December 2010 through July 2011: U.S. Geological Survey Professional Paper 1798-B, 22 p.

Woolpert, Inc., 2011, Louisiana lidar regions 1 and 2: Charleston, South Carolina, National Oceanic and Atmospheric Adminstration, U.S. Geological Survey contract no. G10PC00057, task order no. G10PD02781. 
Publishing support provided by: Rolla Publishing Service Center

For more information concerning this publication, contact: USGS National Wetlands Research Center

700 Cajundome Boulevard

Lafayette, LA 70506-3152

(337) $266-8500$

Or visit the National Wetlands Research Center Web site at: http://www.nwrc.usgs.gov/index.htm/ 



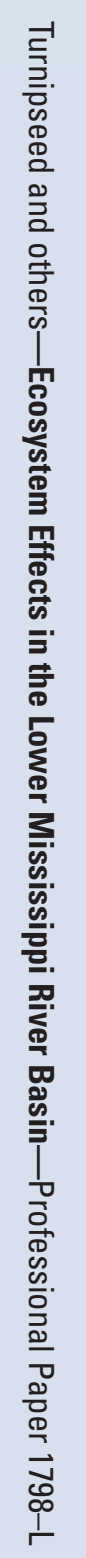

